\title{
The Aristotelian Legacy in Arthur Miller's Concept of Tragedy
}

\author{
Sameh S. HASSAN
}

Suez Canal University

\section{INTRODUCTION}

There are whole libraries of books dealing with the nature of tragedy. That the subject is capable of interesting so many writers over the centuries is part proof that the idea of tragedy is constantly changing, and more, that it will never be finally defined. (Miller, "The Nature of Tragedy," 11)

Starting with Arthur Miller's argument about the impossibility of coming up with an appropriate definition of tragedy due to its changing nature, this paper attempts to examine the influence of Aristotle's theory of tragedy, proposed in his Poetics ${ }^{1}$ in the $4^{\text {th }}$ century BC, on Miller's concept of modern tragedy as given in his theatre essays "Tragedy and the Common Man" (1949), "The Nature of Tragedy" (1949), "On Social Plays" (1955) and "Introduction to Collected Plays" (1958). For many centuries now the Aristotelian theory on tragedy has greatly influenced the creation and critical appreciation of tragedy in western criticism and literature. While writing his theory, Aristotle was influenced by the great classical tragedies of Aeschylus, Sophocles and Euripides from which he managed to point out the common characteristics of a tragedy. Since then, Aristotle's definition of tragedy has been regarded as the standard for taste on which any work that claims to be a tragedy should be evaluated. In this sense, prominent Shakespearean tragedies such as King Lear, Hamlet, Othello and Macbeth that were written during the Renaissance became the subject of numerous critical reviews and studies which were themselves caught in the Aristotelian concept of tragedy as a source of authority and judgment. In his Essay of Dramatic Poetry (1668) John Dryden, for example, justifies the violation of the three unities of drama (time, place and action), derived from Aristotle in the sixteenth century, by English dramatists claiming that 


\section{The Aristotelian Legacy}

the English disregard for the Greek conventions gave greater spirit to their writing, "In most of the irregular plays of Shakespeare or Fletcher (for Ben Johnson's are for the most part regular) there is a more masculine fancy and greater spirit in all the writing, than there is in any of the French" (137). ${ }^{2}$

Likewise, Miller's well-known twentieth-century tragedies, All My Sons, Death of a Salesman, The Crucible and A View from the Bridge, are critically trapped in this constant comparison between Aristotle's theory on tragedy and any literary work to be classified as a tragedy. According to Susan Haedicke, "Much of the scholarship on Miller has focused on questions of genre, particularly, on the concept of tragedy" (280), which Miller discussed in many of his theatre essays. Most critical reviews written about Miller's plays are involved in the debate whether his plays qualify as tragedies or not. Such debate raged more noticeably after the release of Death of a Salesman in 1949. Many critics of Miller at that time had in mind the Aristotelian model of the tragic hero rather than the Aristotelianbased model created by Miller as it appears in the numerous citations from Aristotle's Poetics in their critical writings and the paucity of citations from Miller's critical essays on tragedy. Some just concluded that the play does not qualify as a tragedy while others took liberty to classify the play as something else. For example, Alvin Whitley describes Miller's theory of tragedy as not "feasible" because "He [Miller] is extending the traditional interpretation to embrace demonstrably different emotional effects and that, in the basic matter of personal dignity, Willy Loman may have ended where Hamlet unquestionably began" (262). Similarly, Richard J. Foster argues that the hero of the play is a "pathetic bourgeois barbarian" and the drama is "not a 'tragedy" or great piece of literature" (87-88) because its protagonist does not possess the characteristics of the Aristotelian tragic hero. Eric Mottram criticises Miller's "muddled notions of Greek tragedy and modern psychology" (32). John Gassner too argues that Miller's play is an example of "drame bourgeouise rather than high tragedy" (5). ${ }^{3}$ Lastly, Harold Bloom argues that, "All that Loman actually shares with Lear and Oedipus is aging; there is no other likeness whatsoever. Miller has little understanding of Classical or Shakespearean tragedy; he stems entirely from Ibsen" (1), drawing attention to how both Ibsen and Miller presented 


\section{Sameh S. HASSAN}

the common man as a tragic hero in a society where money is the measure of success.

However, Miller himself answered those critics in his critical essays. In "Ibsen and the Drama of Today," Miller emphasises that "[Ibsen] was a reincarnation of the Greek dramatic spirit" (530), and in "Introduction to the Collected Plays," he warns against applying the Aristotelian model to judge modern plays:

Aristotle having spoken of a fall from the heights, it goes without saying that someone of the common mold cannot be a fit tragic hero. It is now many centuries since Aristotle lived. There is no reason for falling down in a faint before his poetics than before Euclid's geometry, which has been amended numerous times by men with new insight. ("Introduction to the Collected Plays" 125)

Thus, to undermine the tragic value of Miller's plays because they do not replicate the Greek or Renaissance conceptions of tragedy is to ignore the differences between the past and the present and to ignore Miller's purpose in tragedy which is "to point out a historical fact which must be taken into account in any consideration of tragedy, and it is the sharp alteration in the meaning of rank in society between the present time and the distant past" ("Introduction to the Collected Plays"126). It should be noted here that the main focus of this paper is on the relationship between two theories on tragedy, Aristotle's and Miller's, which might help in the criticism of the dramatic work of Miller. However, critics of Miller's plays are free to favour any model of tragedy, be it Aristotle's, Miller's, or any other model, provided that they know what they are doing. Some of the questions that the present paper attempts to answer are how is Aristotle's theory on tragedy relevant to Miller's? And what are the main similarities and differences between the two? To find answers for these questions, a comparison is set between Aristotle's and Miller's theories in terms of the Aristotelian basics of tragedy: spoudaios (tragic nobility), hamartia (tragic flaw), peripeteia (reversal of fortune), anagnorisis (recognition), pathos (suffering) and catharsis (tragic effect). 


\section{The Aristotelian Legacy}

\section{DEFINITION OF TRAGEDY}

A comparison of the essentials of tragedy in Aristotle's and Miller's theories should start with a discussion of what does tragedy mean for both of them. In his Poetics, Aristotle states the general principles of tragedy as follows:

Tragedy ... is an imitation of an action that is serious, complete, and of a certain magnitude; in language embellished with each kind of artistic ornament, the several kinds being found in separate parts of the play; in the form of action, not of narrative; through pity and fear effecting the proper purgation of these emotions. (23)

Aristotle's definition, based on the belief that tragedy is the highest form of literature, agrees with Plato that all the arts are imitations (mimesis). Accordingly, tragedy is an imitation of a "serious" action of a certain "magnitude". Aristotle's emphasis on seriousness (quality) and magnitude (quantity) of action in tragedy implies that there cannot be a tragedy about something trivial or too simple to be a real problem. However, to decide that something is trivial or serious is something that is, just like beauty, in the eye of the beholder. In other words, what seems serious and significant for some at one time is not necessarily as such for others in another time. For example, breaking a fingernail is not as tragic for a soldier in a battlefield as it is for a 6-year-old girl playing in her front yard. Also, that an action should be seen as one of magnitude depends on the importance not only of the action but also of those who are exposed to it. For example, some people might grieve more for the death of their pet than for the death of a sibling or a neighbour. Thus, a serious action or a tragedy differs in terms of quality and quantity from one person to another and from one situation to another.

In his twentieth-century definition of the term, Miller retains a great deal of the essence of the Aristotelian tragedy as a complete, serious action of a certain magnitude. The fact that Miller used the same term, tragedy, that has been used to refer to this sub-genre of drama since the time of Aristotle, definitely reveals that what Miller proposed in his twentieth 


\section{Sameh S. HASSAN}

century critical and dramatic practices has much in common with what Aristotle proposed in the Poetics at least in terms of form. ${ }^{4}$ In "Tragedy and the Common Man", Miller rejects the assumption that tragedy is an archaic form of literature, "For one reason or another, we are often held to be below tragedy - or tragedy above us. The inevitable conclusion is, of course, that the tragic mode is archaic, fit only for the very highly placed, the kings or the kingly" (8). He argues that the notion of tragedy is as equally possible in modern times as it used to be in the past. However, Miller does not give in any part of his essay a definition of tragedy that contradicts Aristotle's notion of tragedy as a serious action of a certain magnitude which implies that the change he proposes in his definition of tragedy has to do with the quality and quantity rather than with the basics of tragedy. Even in the definition of tragedy which Miller offers at the end of "The Nature of Tragedy," it is clear that his concept of tragedy involves Aristotle's:

You are witnessing a tragedy when the characters before you are wholly and intensely realized, to the degree that your belief in their reality is all but complete. The story in which they are involved is such as to force their complete personalities to be brought to bear upon the problem, to the degree that you are able to understand not only why they are ending in sadness, but how they might have avoided their end. The demeanor, so to speak, of the story is most serious - so serious that you have been brought to the state of outright fear for the people involved, as though for yourself.

Miller's definition of tragedy is in many ways similar to that of Aristotle. Both agree that a tragedy, in its broadest definition, is a form of drama that depicts a complete serious story about human suffering that evokes from the audience powerful emotions such as pity and fear.

\section{SPOUDAIOS}

The first concept that Miller challenges in Aristotle's theory is tragic nobility. Miller starts "Tragedy and the Common Man" with the argument that the common man can and should be the main focus of tragedy in 


\section{The Aristotelian Legacy}

modern life "I believe that the common man is as apt a subject for tragedy in its highest sense as kings were" (8). Miller reveals that his main contribution to the development of tragedy is the focus on the "Common Man" in contrast to Aristotle who stated that tragedy is a representation of noble human beings ( spoudaios $^{5}$ ) and that the tragic hero should be "one who is highly renowned and prosperous, - a personage like Oedipus, Thyestes, or other illustrious men of such families" (43). In other words, the tragedy Miller advocates is one that should be written about and for common descent men. The same standpoint is emphasised again at the end of his essay, "It is time, I think, that we who are without kings, took up this bright thread of our history and followed it to the only place it can possibly lead in our time - the heart and spirit of the average man" (10). This assertion on Miller's part draws attention to significant departures from Aristotle's theory. First, Miller implies that the most important part of the tragedy is character. In "The Nature of Tragedy," he asserts that "It is quite possible to write a good melodrama without creating a single living character ... But without a living character it is not possible to create drama or tragedy" (11). In the Poetics, however, Aristotle asserts that the plot (mythos) is the most important element in a tragedy and that character (ethos) is second in importance after plot, "The incidents and the plot are the end of a tragedy; and the end is the chief thing of all. ... without action there cannot be a tragedy; there may be without character" (25).

Second, Miller emphasises the common man's suitability for tragedies, "if the exaltation of tragic action were truly a property of the high-bred character alone, it is inconceivable that the mass of mankind should cherish tragedy above all other forms, let alone be capable of understanding it" ("Tragedy and the Common Man" 8). Miller rejects the idea that tragedy has to do with an individual tragic hero who is better than the average person. However, George Jean Nathan criticises Miller's concept and argues that a common man cannot be a tragic hero because he is "without universal size":

Save the little man has something of a mind, which Mr. Miller's protagonist has not, his tragedy, while it may be moving, is in finality without universal size and is like the experience we suffer in contemplating on the highways a run- 


\section{Sameh S. HASSAN}

over and killed dog, undeniably affecting but without any profound significance. The tragedy, accordingly, becomes that not of a full winged human being but merely that of a mindless clod. (284-85)

Nevertheless, Raymond Williams advocates that the social change in the twentieth century results in a rejection of this tragic nobility based on social stratification in Greek and Renaissance tragedies:

In the person of Agamemnon or of Lear the fate of a house or a kingdom was literally acted out. It was of course inevitable that this definition should fail to outlast its real social circumstances, in its original form. It was in particular inevitable that bourgeois society should reject it: the individual was neither the state nor an element of the state, but an entity in himself. (202)

\section{HAMARTIA}

As stated by Aristotle, the tragic hero is "A man who is not eminently good and just, yet whose misfortune is brought about not by vice or depravity, but by some error or frailty" (43). According to Miller, the concept of tragic flaw in modern tragedy is different:

In the sense of having been initiated by the hero himself, the tale always reveals what has been called his "tragic flaw," a failing that is not peculiar to grand or elevated characters. Nor is it necessarily a weakness. The flaw, or crack in the character, is really nothing — and need be nothing, but his inherent unwillingness to remain passive in the face of what he conceives to be a challenge to his dignity, his image of his rightful status. ("Tragedy and the Common Man" 8)

Miller develops the Aristotelian, as well as Shakespearean, concept of hamartia in many ways: first, hamartia is no longer limited to tragic nobility; second, hamartia is not necessarily an error in judgment (so the tragic hero is guilty without really being so as in Greek tragedy) or a weakness in character (so the tragic hero is responsible for his downfall as 


\section{The Aristotelian Legacy}

in Shakespearean tragedy); and third, the tragic flaw exists more in the society than in the tragic hero. In fact, Miller assumes a critical position against the society in which the tragic hero lives. Unlike Aristotle who argued that the hero's tragic flaw "consists in some moral defect inherent in the tragic hero's character which leads him . . . to consciously and intentionally err in judgment and thereby commit some wrong act" (Stambusky 93), Miller emphasises that the tragic hero's misfortune is partly the result of the act of "a wrong or an evil in his environment":

Now, if it is true that tragedy is the consequence of a man's total compulsion to evaluate himself justly, his destruction in the attempt posits a wrong or an evil in his environment. And this is precisely the morality of tragedy and its lesson.... The wrong is the condition which suppresses man, perverts the flowing out of his love and creative instinct. ("Tragedy and the Common Man" 9)

Essentially, the tragic hero in Miller's tragedy "gains size" and magnitude qualitatively, through his conflict with external circumstances, and quantitatively, in his portrayal in terms of commonness rather than status. In Death of a Salesman, Robert Hogan says, "Willy's story is larger than one man's. Like even the great tragic figures of Sophocles and Shakespeare, Miller's Willy is both an individual and a broadly relevant type" (20). It is in the very action of not being passive in the face of what he conceives to be a challenge to his dignity, that "the character [the common man] gains "size," the tragic stature which is spuriously attached to the royal or the high born in our minds. The commonest of men may take on that stature to the extent of his willingness to throw all he has into the contest, the battle to secure his rightful place in his world" ("Tragedy and the Common Man" 10). In other words, the common man gains heroic greatness in striving against a wrong or an evil in his society. Therefore, the tragic end of the hero is the joint responsibility of his society and his hamartia. In his discussion of the classical Greek playwrights and their contribution to western drama, Miller argues that, "The Greek dramatist had more than a passing interest in psychology and character on the stage. But for him these were means to a larger end, and the end was what we 


\section{Sameh S. HASSAN}

isolate today as social" ("On Social Plays" 68). In this way, tragedy would incorporate both the individual's psychological and social life.

\section{PERIPETEIA}

For Aristotle, a complex plot is a plot which includes characters that have a "reversal of intention' [known as] peripeteia and 'recognition' or anagnorisis" (2). Aristotle defines peripeteia as "a change by which a train of action produces the opposite of the effect intended" (37). This change of fortune, Aristotle stated, "should be not from bad to good, but, reversely, from good to bad. It should come about as the result not of vice, but of some great error or frailty in a character" (43). The question that should be asked is: does Miller merely replicate the Aristotelian plot? A closer look at examples of criticism on Miller's modern tragedies reveals that he arranged the incidents of his tragedies in a manner that is, in one way or another, comparable to the Aristotelian plot. Susan Abbotson argues that Miller's plays are all tragic in structure although they are just about average people:

Although Miller extends the parameters of the Greek formula, he does not change its essential format. Plays such as All My Sons and A View from the Bridge . . . are clearly tragic in structure; Joe Keller and Eddie Carbone are tragic heroes with flawed natures that lead them astray but also with firm consciences that help bring them to justice. Willy Loman is certainly not a classic tragic hero being lowermiddle class and none too clever. (465)

In "Death of a Salesman: Tragic Myth in the Modern Theatre" (1963), Esther Merle Jackson asserts that Miller makes his protagonist, just like any tragic hero in Aristotle's theory, "The subject of moral exploration [that] stirs the modern spectator at the alternately joyful and painful periphery of consciousness which is the province of tragedy" (64). In this sense, the modern tragic hero's shift of fortune from good to bad is connected to the common man's dream of prosperity and success thwarted by capitalism.

As argued by Abbotson and Jackson, Miller has created plays which are structurally modelled on Aristotelian Greek tragedy. However, as many 


\section{The Aristotelian Legacy}

modern critics noted, the Aristotelian concept of peripeteia has changed under the influence of Miller. Atma Ram notes that, "In Death of a Salesman, for example, the so-called reversal of fortune of the protagonist is not brought about in the Greco-Elizabethan manner of Oedipus or King Lear. The expressionistic plot of the play, by blurring the temporal and spatial outlines, makes the past and the present exist in a state of simultaneity" (8). In this sense, Santosh K. Bhatia argues that "The reversal of fortune or peripeteia has already taken place before the play begins" (50). Clifford Leech argues that Aristotle's concept of peripeteia is by no means obligatory but only valuable in achieving the tragic effect. Therefore, Leech claims, the concept of peripeteia works with plays such as King Lear and Othello in which "Lear and Othello acted so as to gain peace and found its opposite ... But the concept will not work at all ... with Arthur Miller's Eddie Carbone (who is desperate from the start)" (63). However, such critical views confirm nothing but Miller's experimentation with the original Greek tradition of peripeteia. In one play, there could be several changes of fortune. In another, the reversal of fortune takes place even before the actual beginning of the play.

\section{ANAGNORISIS}

Similarly, Miller changes the Aristotelian concept of anagnorisis to suit the parameters of modern life. In Aristotle's theory, anagnorisis describes "a change from ignorance to knowledge, producing love or hate between the persons destined by the poet for good or bad fortune" (39). In "Tragedy and the Common Man," Miller makes it clear that anagnorisis involves more than the hero's insight into a relationship with another character, "The discovery of the moral law, which is what the enlightenment of tragedy consists of, is not the discovery of some abstract or metaphysical quantity. The tragic night is a condition of life, a condition in which the human personality is able to flower and realize itself" (9). For Miller, anagnorisis or enlightenment is the discovery of a general rule of right living rather than a discovery of nonspecific transcendent reality. In "The Nature of Tragedy," Miller argues that knowledge of the right way of living in the world is the main difference between the tragic and the pathetic: 


\section{Sameh S. HASSAN}

When Mr. B., while walking down the street, is struck on the head by a falling piano, the newspapers call this a tragedy. In fact, of course, this is only the pathetic end of Mr. B. Not only because of the accidental nature of his death; that is elementary. ... To my mind the essential difference, and the precise difference, between tragedy and pathos is that tragedy brings us not only sadness, sympathy, identification and even fear; it also, unlike pathos, brings us knowledge or enlightenment. But what sort of knowledge? In the largest sense, it is knowledge pertaining to the right way of living in the world. (11-12)

Is there any similar distinction between tragedy and pathos in Aristotle's Poetics? The answer is 'yes'. Aristotle argued that the tragic wonder will be greater if the events of the tragedy are carefully designed "than if they happened of themselves or by accident; for even accidents are most striking when they have an air of design. We may instance the statue of Mitys at Argos, which fell upon his murderer while he was looking at it, and killed him. Such events seem not to be due to mere chance" (37). To distinguish between tragic events and pathetic accidents, both Aristotle and Miller gave the example of something that falls on someone and leaves him dead. Whereas the death of Mitys's murderer is seen by Aristotle as tragic, the death of Mr. B. is seen by Miller as pathetic. The difference between the two events lies in what Aristotle refers to as design. Unlike the death of Mr. B which brings about no knowledge or illumination, the death of Mitys's murderer by the statue of Mitys while he was a spectator at a festival is a kind of poetic justice intended to inspire proper moral behaviour in its audience by illustrating the triumph of good over evil. Such knowledge or illumination is achieved by the audience through the casual link between the two events of Mitys's murder and the subsequent death of Mitys's murderer.

In essence, Aristotle's anagnorisis and Miller's enlightenment are very much alike. Scott Hurley notes that the Greek tragedy was supposed to instruct and not just entertain, "Greek tragedies were meant to instruct and the stories were well known. Greek audiences did not attend tragedies to find out what happened, but rather to learn something from the playwright's 


\section{The Aristotelian Legacy}

treatment of a familiar story" (7). However, there are still differences between Aristotle and Miller in regard to treatment of anagnorisis. Rolf Soellner emphasizes that "Miller's, as well as Aristotle's, ideas of selfknowledge are too deeply rooted in their respective cultures" (xiii). Indeed, Maxwell Anderson notes that "In the mechanism of a modern play it is almost invariably a discovery of the hero of some element in his environment, in his soul, of which he has not been aware - or which he has not taken sufficiently into account epiphany" (qtd. in Atma Ram, 8). In "Introduction to the Collected Plays," Miller makes it clear that his protagonists, particularly Willy of Death of a Salesman, achieve anagnorisis:

Had Willy been unaware of his separation from the values that endure he would have died contentedly while polishing his car, probably on a Sunday afternoon with the ball game coming over the radio. But he was agonized by his awareness of being in a false position, so constantly haunted by the hollowness of all he had placed his faith in, so aware, in short, that he must somehow be filled in his spirit or fly apart, that he staked his very life on the ultimate assertion. That he had not the intellectual fluency to verbalise his situation is not the same thing as saying that he lacked awareness. (127)

In other words, the modern tragic hero may lack "the intellectual fluency to verbalise his situation," but he must be aware of the situation that makes him sacrifice his life. Therefore, Stephen Marino regards Willy's final suicide as "a logical extension of his character who cannot be expected to abandon his dreams because he has achieved anagnorisis" (44). Commenting on anagnorisis in the play, Peter L. Hays argues that "There are two in the play," Willy's recognition that his values are flawed and Biff's recognition that Willy had the wrong dreams. Likewise, Satyendra Kumar notes that in Miller's All My Sons "The Anagnorisis . . . comes in stages" (86). This reveals that anagnorisis is there in modern tragedy but it has become more sophisticated than it was in Greek or Renaissance tragedies. 


\section{Sameh S. HASSAN}

\section{PATHOS}

According to Aristotle, pathos is a third part of the plot along with peripeteia and anagnorisis. Aristotle defines pathos ${ }^{6}$ or "suffering" as "a destructive or painful action, such as death on the stage, bodily torments, wounds and the like" (39). Aristotle's Poetics recommends that playwrights locate the pathos in the fifth act with the hero's fall. The social relationship between the characters involved in the pathos is one of the circumstances that cause it to be terrible and pitiful as argued by Aristotle:

If an enemy kills an enemy, there is nothing to excite pity either in the act or the intention, - except so far as the suffering in itself is pitiful. ... But when the tragic incident occurs between those who are near or dear to one another if, for example, a brother kills, or intends to kill, a brother, a son his father, a mother her son, a son his mother, or any other deed of the kind is done - here we have the situations which should be sought for by the poet. (47)

But what is pathos for Miller? Commenting on the death of Eddie Carbone, the protagonist of his play A View from the Bridge, Miller says:

Thus his "oddness" came to disappear as he was seen in context, as a creature of his environment as well as an exception to it; and where originally there had been only a removed sense of terror at the oncoming catastrophe, now there was pity and, I think, the kind of wonder which it had been my aim to create in the first place. It was finally possible to mourn this man. ("Introduction to the Collected Plays"139)

Also John Gassner argues that in Death of a Salesman, "Willy pursues truth and struggles against it within his personal and social limits no less arduously and catastrophically than Oedipus. Thus, Miller's protagonist brings not only personal and social meanness into the play, but also personal stature and heroism" (139). What is common in the experience of pathos in the two cases is the constant concern of Miller's plays with the 


\section{The Aristotelian Legacy}

individual in/against society. Society plays a significant role in what the tragic hero is and what he does. It is when man fails to find his place in society that pathos occurs. Miller says in the preface to The Crucible, "It is still impossible for man to organize his social life without repressions, and the balance has yet to be struck between order and freedom" ("Introduction to The Crucible" 8). However, none of Miller's tragic heroes succeeds in striking such a balance. ${ }^{7}$

It has long been debated among critics whether the pathos should always end happily, and whether virtue is always to be rewarded and vice punished. Aristotle, for example, prefers an appalling pathos, rather than a joyful one because the tragic effects of terror and pity, which is the aim of tragedy, are better created by the former than the latter. One of the key differences between Aristotle and Miller regarding pathos is emphasised by Miller in his claim that:

Tragedy called a more exalted kind of consciousness, is so called because it makes us aware of what the character might have been. . . . Tragedy therefore is inseparable from a certain modest hope regarding the human animal. And it is the glimpse of this brighter possibility that raises sadness out of the pathetic toward the tragic. ("The Nature of Tragedy"12)

Miller believes that the death of the tragic hero in this sense represents a kind of tragic victory:

A man's death is and ought to be an essentially terrifying thing and ought to make nobody happy. But in a great variety of ways even death, the ultimate negative, can be, and appear to be, an assertion of bravery, and can serve to separate the death of man from the death of animals; and I think it is this distinction which underlies any conception of victory in death. For a society of faith, the nature of the death can prove the existence of the spirit, and posit its immortality. For a secular society it is perhaps more difficult for such a victory to document itself and to make itself felt, but conversely, the 


\section{Sameh S. HASSAN}

need to offer greater proofs of the humanity of man make that victory more real. ("Introduction to the Collected Plays"127)

Thus, Miller rejects the idea that "tragedy is of necessity allied to pessimism" ("Tragedy and the Common Man"10) and debates that the pathos should be optimistic, leaving the audience broken-hearted, but with the knowledge that the protagonist comes to know himself, or dies on his own terms, "In truth tragedy implies more optimism in its author than does comedy, and that its final result ought to be the reinforcement of the onlooker's brightest opinions of the human animal" ("Tragedy and the Common Man" 10). ${ }^{8}$

\section{CATHARSIS}

In the Poetics, Aristotle states that catharsis, a mixed response of pity (eleos) and fear (phobos), is the main purpose of a tragedy. Thus a combination of peripeteia, anagnorisis and pathos "will produce either pity or fear; and actions producing these effects are those which, as we have assumed, Tragedy represents" (39). The aim of tragedy, Aristotle points out, is to bring about a "catharsis" of the spectators - to arouse in them sensations of pity and fear, and to purge them of these emotions so that they leave the theater feeling cleansed and uplifted. Commenting on Aristotle's conception of the tragic feelings of pity and fear, Leon Golden notes that the audience may feel empathy for the tragic man because his story is believable and common:

According to Aristotle, the emotions represented and evoked in tragedy are pity and fear. He defines pity as the emotion we feel toward someone who has suffered undeserved misfortune, and fear as the emotion we feel when we realize that the one who suffers this misfortune is someone like ourselves. Now, pity and fear, when we experience them in actual life, are painful feelings, but when they occur in tragic mimesis they are integrated into a structure that has the production of intellectual pleasure as its goal. ("Aristotle", para. 6). 


\section{The Aristotelian Legacy}

But does Aristotelian tragic feeling of pity and fear change in correspondence to the cultural context of tragedy? Bradley Rubidge argues, "Because emotions are socially constructed, and because social organization and ideas about human nature and psychology change, the theory and practice of emotion also change" (317). Therefore, one action will not invoke the same emotional response in Ancient Greek spectators and those in twentieth-century Western societies. In other words, the effect produced by a tragedy, i.e. catharsis, depends on the cultural expectations of the audience. Whereas Aristotle's concept of the tragic effect is mainly dependent on the audiences' awareness of the tragic hero's errors and the inevitable nature of fate, Miller's concept is based on feelings of pity and fear aroused in the individually empowered audience of the twentieth century out of their awareness of the tragic hero's deliberate endeavor to secure his personal dignity, leading to self-sacrifice:

I think the tragic feeling is evoked in us when we are in the presence of a character who is ready to lay down his life, if need be, to secure one thing his sense of personal dignity. From Orestes to Hamlet, Medea to Macbeth, the underlying struggle is that of the individual attempting to gain his "rightful" position in his society. Sometimes he is one who has been displaced from it, sometimes one who seeks to attain it for the first time, but the fateful wound from which the inevitable events spiral is the wound of indignity and its dominant force is indignation. ("Tragedy and the Common Man" 8)

Miller redefines the Aristotelian concept of catharsis arguing that in modern tragedy pity and fear are invoked in the audience by the protagonist who acts "against the scheme of things that degrades them" (8), or challenges the existing state of affairs and therefore reveals that the world that we consider to be secure and stable is hazardous and unsettled. Miller argues that it is "this total onslaught by an individual against the seemingly stable cosmos surrounding us - from this total examination of the 'unchangeable' environment - comes the terror and the fear that is classically associated with tragedy" ("Tragedy and the Common Man" 9). 


\section{Sameh S. HASSAN}

In relation to catharsis in Miller's drama, Eric Bentley argues that Miller wrote social drama rather than significant tragedies of the highest order and that, "The theme of this social drama [Death of a Salesman], as of most others, is the little man as victim. Such a theme arouses pity, but no terror. Man is here too little and too passive to play the tragic hero" (85). Yet, Miller contends that the tragic fear that modern tragedy evokes in the audience is even stronger than that of the audience of Greek or Renaissance tragedies, "Among us today this fear is strong, and perhaps stronger, than it ever was. In fact, it is the common man who knows this fear best" (9). Ironically, Aristotle himself emphasises that "Pity is aroused by unmerited misfortune, fear by the misfortune of a man like ourselves" (43). Miller argues that Greek tragedies that are built on the concept of tragic nobility will not inspire in the modern audience the feeling of fear because they do not see themselves in their protagonists:

Insistence upon the rank of the tragic hero, or the so-called nobility of his character, is really but a clinging to the outward forms of tragedy. If rank or nobility of character was indispensable, then it would follow that the problems of those with rank were the particular problems of tragedy. But surely the right of one monarch to capture the domain from another no longer raises our passions, nor are our concepts of justice what they were to the mind of an Elizabethan king. ("Tragedy and the Common Man" 9)

In this sense, Miller implies that his plays are as tragic, if not more tragic, than Renaissance and Greek tragedies. This is mainly because the audience now is able to identify with the problems of the common man more than "the problems of those with rank". 


\title{
The Aristotelian Legacy
}

\section{CONCLUSION}

Based on the comparison between Aristotle's and Miller's concepts of tragedy, one can say that Aristotle's and Miller's theories are more similar than they are different. Miller's theory embodies, for many, the concepts that Aristotle found essential for all great tragedies. However, in his attempt to reapply tragedy to modern life, Miller redefines the Aristotelian concepts of tragedy such as spoudaios, hamartia, peripeteia, anagnorisis, pathos and catharsis so as to meet the cultural expectations of the audience in twentieth-century American society. The main difference between the two lies in the function of tragedy rather than its form. Miller agrees with Aristotle's basic structure of a tragedy, but they could not disagree more on the characteristics of the "tragic hero." While Aristotle's tragic hero is a man of stature whose downfall should be perceived as a horrible, pessimistic story, Miller's tragic hero is a common man, and his downfall should evoke optimism by the presence of the possibility of his victory.

\begin{abstract}
NOTES
${ }^{1}$ Key concepts and definitions of Aristotle's theory are quoted from S. H. Butcher's translation of the Poetics as the "most popular and generally influential of English works on the Poetics" (Gilbert: 66).

${ }^{2}$ According to Robert Royce Miller, "Shakespeare is frequently called into the argument between Miller and the ancients" (132). Unlike Shakespeare, Miller patterned his tragedies on the three unities of time, space and action, derived from Aristotle's Poetics. Sometimes he used the flashback technique to move freely in space and time and at the same time keep the unity of place and time intact.

${ }^{3}$ The term drame bourgeois is defined in The Reader's Encyclopedia of World Drama as "A term used in the late eighteenth century to designate serious, and often sentimental, plays that show that man is essentially good but misled by social prejudices" (187). Unlike classical and Renaissance tragedies in which the protagonists are of kingly or aristocratic rank, drame bourgeois is characterised by the fact that its protagonists are ordinary citizens. According to Merriam-Webster's Encyclopedia of Literature, "The drame bourgeois was conceived of as occupying a place between tragedy and comedy. It was designed as a serious depiction of middle-class problems, especially social abuses, but usually included a conventional happy ending" ("drame bourgeois" 346 ).

${ }^{4}$ Miller admits that early in his life he was attracted to the form of classical Greek plays, "I had no background at that time to know really what was involved in those plays, but the
\end{abstract}




\section{Sameh S. HASSAN}

architecture was clear. One looks at some building of the past whose use one is ignorant of, and yet it has modernity. It had its own specific gravity. That form has never left me; I suppose it just got burned in" (Olga, and Styron 217).

${ }^{5}$ Paul A. Cantor argues that the Greek word spoudaios, normally translated as good or serious, should be translated as noble to keep the focus on the elevated status of the Aristotelian tragic hero, "Aristotle understands spoudaios in contrast to phaulos, and that together the two terms reflect the hierarchy of aristocratic society in ancient Greece, Spoudaios characterizes the way of life of the Greek hero or warrior or noble; phaulos the way of life of the ordinary man, the slave, or the commoner" (65).

${ }^{6}$ Charles Batteux uses the term "catastrophe" to render pathos in his French translation of Aristotle's Poetics. According to Knut Ove Eliassen, Aristotle did not employ the term "catastrophe" in The Poetics (38).

${ }^{7}$ Miller believes that the twentieth century is a complex and confusing era, not just for the individual but also for the writer, "Maybe that's why, it's so difficult to arrive at a satisfactory dramatic form now, because society is so contradictory that the vocabulary can't socialize experience anymore" ("Interview: Ronald Hayman/1970" 194).

${ }^{8}$ That tragedy is optimistic leads Miller, as stated by Julian Young, to take a position on the role of fate in tragedy, "In the hero's conflict with the established order, 'the possibility of victory must be there'. If it is not then we have, indeed, a pessimistic outlook, in which the hero is no longer heroic but merely "pathetic" (251).

\section{WORKS CITED}

Abbotson, Susan. Critical Companion to Arthur Miller: A Literary Reference to His Life and Work. New York: Infobase, 2007.

Aristotle. The Poetics. Trans. S.H. Butcher, London: Macmillan, 1895.

Bentley, Eric. In Search of Theater. New York: Alfred A. Knopf Inc., 1953.

Bhatia, Santosh K. Arthur Miller: Social Drama as Tragedy. New York: Humanities, 1985.

Bloom, Harold. "Introduction to Willy Loman." Bloom's Major Literary Characters. New York: Chelsea House, 1991.

Cantor, Paul A. "Aristotle and the History of Tragedy." Theoretical Issues in Literary History. Ed. David Perkins. Cambridge and

Massachusettes: Harvard University Press, 1991. 60-84.

"Drame bourgeois." Merriam-Webster's Encyclopedia of Literature.

Springfield, Massachusettes: Merriam-Webster, 1995. 


\section{The Aristotelian Legacy}

Dryden, John. "From An Essay of Dramatick Poesie 1668." William

Shakespeare: The Critical Heritage, Volume I 1623-1692. Ed.

Brian Vickers. London: Routledge, 1995. 136-40.

Eliassen, Knut Ove. "Catastrophic Turns - From the Literary History of the Catastrophic." The Cultural Life of Catastrophes and Crises. Eds.

Carsten Meiner and Kristin Veel. Berlin: Walter de Gruyter, 2012.

Foster, Richard J. "Confusion and Tragedy: The Failure of Arthur Miller's

Salesman." Two Modern American Tragedies: Reviews and Criticism

of Death of a Salesman and A Streetcar Named Desire. Ed. John D.

Hurrell. New York: Charles Scribner's, 1961. 82-88.

Gassner, John. "The Theatre Arts." The Merrill Studies in Death of a

Salesman. Ed. Walter J. Meserve. Columbus: Merrill, 1972.

Gassner, John and Quinn, Edward. The Reader's Encyclopedia of World

Drama. New York: Dover Publications, 2002.

Gilbert, Allan H. Literary Criticism: Plato to Dryden. New York: American Book Company, 1940.

Golden, Leon. “Aristotle”. Florida International University. 1997. Web 4

Nov. 2015. 〈http://comptalk.fiu.edu/aristotle.htm〉.

Haedicke, Susan. "Arthur Miller: A Bibliographic Essay.” The Cambridge

Companion to Arthur Miller. Ed. Christopher Bigsby. Cambridge:

Cambridge University Press, 2010. 273-94.

Hays, Peter L. Arthur Miller's Death of a Salesman. London: Bloomsbury, 2015.

Hogan, Robert G. Arthur Miller. Minneapolis: University of Minnesota Press, 1964.

Hurley, Scott. A View from the Bridge: Insight Text Guide. Mentone, Vic.: Insight, 2004.

Jackson, Esther Merle. "Death of a Salesman: Tragic Myth in the Modern

Theatre”. CLA Journal, Vol. 7, September 1963: 63-76.

Kumar, Satyendra. The Allegory of Quest: A Study in Arthur Miller's

Plays. New Delhi: Kalpaz, 2004.

Leech, Clifford. Tragedy. London and New York: Routledge, 2002. 


\section{Sameh S. HASSAN}

Marino, Stephen. Arthur Miller - Death of a Salesman/The Crucible. New York: Palgrave/Macmillan, 2015.

Miller, Arthur. "Ibsen and the Drama of Today." The Collected Essays of Arthur Miller. London: Bloomsbury, 2016. 529-32.

--- "Introduction to the Collected Plays." The Collected Essays of Arthur Miller. London: Bloomsbury, 2016. 107-41.

--- "Introduction to The Crucible". The Crucible. London: Bloomsbury, 2015.

--- "Interview: Ronald Hayman/1970." Conversations with Arthur Miller.

Eds. Matthew Charles Roudané and Arthur Miller. Mississippi:

University Press of Mississippi, 1987. 187-99.

--- “On Social Plays.” The Collected Essays of Arthur Miller. London: Bloomsbury, 2016. 68-78.

--- "The Nature of Tragedy." The Collected Essays of Arthur Miller.

London: Bloomsbury, 2016. 11-13.

--- "Tragedy and the Common Man." The Collected Essays of Arthur

Miller. London: Bloomsbury, 2016. 8-10.

Miller, Robert Royce. "Tragedy in Modern American Drama: The

Psychological, Social, and Absurdist Conditions in Historical

Perspective." Ph.D. Thesis. Graduate Faculty of Middle Tennessee

State University, 1975.

Mottram, Eric. "Arthur Miller: The Development of a Political Dramatist in America." Arthur Miller: Collection of Critical Essays. Ed. Robert Corrigan. New Jersey: Prentice, 1969.

Nathan, George Jean. "The Theatre”. American Mercury, June 1949.

Olga, Carlisle and Styron, Rose. "Arthur Miller: An Interview." The

Collected Essays of Arthur Miller. London: Bloomsbury, 2016. 21634.

Ram, Atma. Perspectives on Arthur Miller. New Delhi: Abhinav, 1988.

Rubidge, Bradley. "Catharsis through Admiration: Corneille, Le Moyne, and the Social Uses of Emotion." Modern Philology: A Journal 


\section{The Aristotelian Legacy}

Devoted to Research in Medieval and Modern Literature. 95.3, 1998: 316-33.

Soellner, Rolf. Shakespeare's Patterns of Self-knowledge. Columbus: Ohio State University Press, 1972.

Stambusky, Allen A. "Arthur Miller: Aristotelian Canons in the Twentieth Century Drama." Modern American Drama: Essays in Criticism.

Ed. William E. Taylor. Florida: Edwards, Inc., 1968. 91-115.

Whitley, Alvin. "Arthur Miller: An Attempt at Modern Tragedy."

Transactions of the Wisconsin Academy of Science, Arts, and Literature, Vol. 42, 1953: 257-62.

Williams, Raymond. Modern Tragedy. London: Chatto and Windus, 1966.

Young, Julian. The Philosophy of Tragedy: From Plato to Žižek. Cambridge: Cambridge University Press, 2013. 